\title{
Phonological features of child African American English
}

Holly K Craig; Connie A Thompson; Julie A Washington; Stephanie L Potter Journal of Speech, Language, and Hearing Research; Jun 2003; 46, 3; Research Library pg. 623

\section{Phonological Features of Child African American English}

Holly K. Craig

Connie A. Thompson Julie A. Washington Stephanie L. Potter University of Michigan Ann Arbor
The production of phonological features of African American English (AAE) was examined for 64 typically developing African American children in the 2nd through the 5th grade. Students read aloud passages written in Standard American English. Sixty of the students read the passages using AAE, and 8 different phonological features were represented in their readings. Phonological features were more frequent than morphosyntactic features. The findings as a whole support use of the toxonomy developed for this investigation in characterizing the phonological features of child AAE.

KEY WORDS: African American English, children's phonology, dialect, cultural linguistic differences

$\mathrm{T}$ his investigation was designed to characterize the phonological features of African American English (AAE) produced by typically developing African American students during the elementary school years. Most African American students enter school speaking AAE. For example, using a continuous enrollment process from received consent forms, a research program at the University of Michigan found that all children in a 4- to 6-year-old cohort of students entering public school in Metropolitan Detroit were speakers of AAE (Craig \& Washington, 2002). Because AAE may be quite frequent among African American students, it seems important to understand its use in different language and literacy contexts.

Before the $1990 \mathrm{~s}$, information about AAE was generated primarily from the study of older adolescents and adults (Dillard, 1972; Fasold \& Wolfram, 1970; Labov, 1972; Stewart, 1970; Wolfram, 1971). Information about child AAE was lacking, particularly the inventory of features used by children at different points in development, the course of acquisition of the feature systems, and the sources of systematic variation influencing production of AAE. Over the last decade, intensive investigation directed at large numbers of African American children has led to increased understanding of some aspects of child AAE, especially for very young students at the time of school entry (Ball, 1994; Craig \& Washington, 1994, 1995, 2002; Craig, Washington, \& Thompson-Porter, 1998a, 1998b; Seymour, Bland-Stewart, \& Green, 1998; Washington \& Craig, 1992, 1994, 1999, 2001, 2002; Washington, Craig, \& Kushmaul, 1998).

Preschool and kindergarten African American students produce up to 16 different morphosyntactic types of AAE (Washington \& Craig, 1994; Washington et al., 1998). Some morphosyntactic features are widely dispersed across students. For example, optional inclusion or exclusion of 
the copula or auxiliary ("This _ how you do it") appeared in the oral language productions of 88 of the 100 preschoolers and kindergartners described by Craig and Washington (2002). Other morphosyntactic features are low frequency, for example, double copulas, auxiliaries or modals ("I'm is the last one ridin' on"). Some morphosyntactic features that are used by adult caregivers are not produced by their young children, particularly those requiring advanced knowledge of verb constituents, for example, completive done ("I think we done ate enough").

The frequencies of occurrence of morphosyntactic forms of child $\mathrm{AAE}$ are influenced by both intrinsic and extrinsic factors. For preschoolers, increased levels of AAE relate to increased levels of syntactic and semantic sophistication (Craig \& Washington, 1994, 1995). Again for preschoolers and kindergartners, boys produce significantly more AAE in their spontaneous discourse than girls, at approximately twice the amount (Craig \& Washington, 2002; Washington \& Craig, 1994, 1998). Low socioeconomic status (SES) relates to higher levels of AAE when low SES is determined by the young student's eligibility for the free or reduced-price lunch program based on federal guidelines (Washington \& Craig, 1998).

The characterization of child AAE remains critically incomplete, however, without complementary description of the phonological features. For young children of preschool and kindergarten ages, identification of phonological forms that are AAE features is very difficult. The immaturity of the oral motor systems of young AAE speakers is a barrier to determining whether specific speech patterns reflect the operation of an AAE feature or a phonological process. For example, Seymour and Seymour (1981), in one of the few studies examining the phonological patterns of African American students, compared the consonant errors of AAE- and SAE-speaking 4- and 5-year-old children. Seymour and Seymour found that the oral productions of both AAE- and SAE-speaking children included the simplification of consonant clusters, a major feature of adult AAE. Similarly, they found that final consonant deletion, another major feature of adult AAE, was evidenced in the oral productions of both their AAE- and SAE-speaking participants, although the AAE speakers produced the phonological form at higher frequencies than did the SAE speakers. Consistent with Seymour and Seymour's (1981) observations, Haynes and Moran (1989) found increased frequencies of final consonant deletions for AAE- compared to SAE-speaking students. In addition, they observed that the mean number of final consonant deletions decreased by approximately half between preschool and third grade. The findings of these two studies underscore the challenges of ascribing feature status to the phonological forms of younger African American students.

Nevertheless, at this time there is a pressing need to understand the phonological features of child AAE because of the importance of phonology to reading processes. Current models of reading acquisition assign central importance to phonological awareness skills (Bus \& van Ijzendoorn, 1999; Goswami, 2001; Hecht, Burgess, Torgesen, Wagner, \& Rashotte, 2000; Torgesen, Wagner, Rashotte, Burgess, \& Hecht, 1997) and to the acquisition of (SAE) phoneme-grapheme correspondences (Adams, 1990, 2001; Ehri et al., 2001; Foorman, 1995; Foorman \& Torgesen, 2001). Theoretically, differences in phonology may affect the establishment of phoneme-grapheme links during reading acquisition. Across the nation, the prevalence of reading below basic levels is much greater for African American than for White students, $63 \%$ compared to $27 \%$ on the 2000 administration of the National Assessment of Education Progress (NAEP; Donahue, Finnegan, Lutkus, Allen, \& Campbell, 2001). Improved understanding of child $\mathrm{AAE}$ in the context of widespread failure to increase the reading levels of so many African American students indicates that revisiting the $\mathrm{AAE} / \mathrm{reading}$ link is warranted. Research of this type, however, awaits information about the phonological features used by AAE-speaking students.

The purpose of this investigation is to contribute to this line of research by describing the phonological features produced by AAE-speaking students in the elementary grades. Elementary-grade students were selected to avoid the challenges of interpreting omitted forms when speakers are more motorically immature. The following questions were posed:

1. What are the phonological features characterizing the oral productions of typically developing African American students enrolled in the second through the fifth grades?

2. How common are the phonological features across students?

3. How do the rates of phonological features compare to the rates of morphosyntactic features produced by the same children?

\section{Method Participants}

The participants were 64 typically developing African American second- through fifth-grade students living in Michigan. All of the students were speakers of AAE and produced two or more features during spontaneous oral discourse. 
Recruitment was initiated by the school principals, and students were included in this study on a continuous enrollment basis during the winter and spring school terms. Grade, gender, and SES were allowed to vary. Grade was allowed to vary as long as students were enrolled in the second through the fifth grades. Second grade was selected for the lower end of the cohort because most children are learning to read conventionally by this grade. Fifth grade was chosen as the upper end because in these schools, fifth grade is the last grade of elementary school.

The participants were 29 boys and 35 girls. In addition, 19 of the students were from low SES homes and 44 were from middle SES homes. SES was determined from one or both of the following sources: the participants' eligibility or ineligibility to participate in the federally funded free or reduced-price lunch program, and/or the Hollingshead Four Factor Index of Social Status (Hollingshead, 1975) derived from caregiver questionnaires. This index assigns point scores based on the occupation, years of schooling, marital status, and gender of the child's primary caregiver(s). The point totals correspond to one of five levels designed to index a family's socioeconomic status. Following the Hollingshead criteria, low SES was assigned to Levels 4 and 5 if the household was comprised of a married couple. Low SES was also assigned if the head of household was female and her scores corresponded to Levels 3,4 , or 5. Middle SES was assigned if the family did not fit the criteria for low SES.

Only children who appeared to be typically developing were enrolled in this investigation. The children were judged to be typically developing by their teachers and parents and had no history of referral to, nor enrollment in, special education services of any type. In addition, each child was administered the Triangles subtest of the Kaufman Assessment Battery for Children (K-ABC, Kaufman \& Kaufman, 1983). This subtest is a matching task that taps a fairly general cognitive skill, is appropriate for children in this age range, and evidences no racial or cultural biases (Kaufman, 1973; Lampley \& Rust, 1986; Palmer, Olivarez, Willson, \& Fordyce, 1989; Willson, Nolan, Reynolds, \& Kamphaus, 1989). Each student achieved a scaled score of 7 or more, performance within one standard deviation $(-3)$ of the mean (10), indicating that the participants were within normal limits cognitively. The mean Triangles scaled score for the group was $10.4(S D=2.2)$. In addition to typical cognitive skill, the oral language of the participants appeared to be typically developing as well, based on average performances on the Peabody Picture Vocabulary Test-III (PPVT-III, Dunn \& Dunn, 1997). The mean standard score on the PPVT-III was $97.0(S D=11.8)$.

\section{Data Collection and Analysis}

Prior research with preschoolers and kindergartners elicited morphosyntactic features of $\mathrm{AAE}$ in spontaneous types of discourse in the context of play with toys or descriptions of activity pictures (Washington \& Craig, 1994, 1998; Washington et al., 1998). A disadvantage of child-centered language sampling of these types is that the transcriber may have difficulty identifying the intended targets for production. Accordingly, for the purposes of the present project, oral reading was selected as the elicitation context. The context of reading aloud is advantageous for transcription and scoring because the intended target is known as long as the child is reading within his or her own level of reading competency.

The Gray Oral Reading Tests, Third Edition (GORT3; Wiederholt \& Bryant, 1992) was selected as the elicitation context for the oral reading samples. The GORT-3 offered the investigation a set of language samples that increased in difficulty, but with the use of basals and ceilings allowed sampling of each child's reading within his/her own skill level. All reading passages in the GORT3 are organized as paragraphs about a single topic. The passages varied from easiest to hardest in terms of increased paragraph length, sentence length, vocabulary difficulty, and grammatical complexity. The GORT-3 was administered individually to each participant following standardized administration procedures. Both child and examiner wore head microphones and were audiorecorded in a quiet room in the child's school.

All variations from print were identified. A dialect density measure (DDM; Craig \& Washington, 2000), calculated as the number of AAE tokens divided by the total number of words read, was used to quantify participants' dialect usage. A two-step process was employed to characterize those variations that were phonological in nature that occurred during oral reading and that might be attributable to the operation of an AAE feature. First, all phoneme variations from SAE were identified, and then these were examined for patterns described in the literature for adult AAE using comprehensive summaries provided by Wolfram (1994) and Stockman (1996), and from preliminary child-based studies that included southern regional dialect as well (Hinton \& Pollock, 2000; Oetting \& McDonald, 2001; Rodekohr \& Haynes, 2001). The resultant taxonomy included $9 \mathrm{AAE}$ phonological features. Table 1 presents the $9 \mathrm{AAE}$ phonological features, 24 morphosyntactic features, and 8 combination features.

Morphosyntactic forms of AAE were scored using Washington and Craig's (2002) definitions for 24 features (see Table 1). Five of the 24 morphosyntactic features could combine with 2 of the phonological features, and these were designated as combinations. Although Labov, Baker, Bullock, Ross, and Brown (1998) argued 
Table 1 (page 1 of 2). Phonological (9), morphosyntactic (24), and combination (8) types of child AAE with examples.

\begin{tabular}{|c|c|c|}
\hline Definition & Code & Example \\
\hline \multicolumn{3}{|c|}{ Phonological types } \\
\hline $\begin{array}{l}\text { 1. Postrocalic consonant reduction } \\
\text { Deletions of consonant singles following vowels }\end{array}$ & PCR & $\begin{array}{l}\text { "mouth" } \\
/ \text { mav/ for /mave/ }\end{array}$ \\
\hline $\begin{array}{l}\text { 2. " } g \text { " dropping } \\
\text { Substitutions of } / 11 / \text { for } / \mathrm{y} / \text { in final word positions }\end{array}$ & $g$ & $\begin{array}{l}\text { "waiting" } \\
\text { /wetin/for /wetn] / }\end{array}$ \\
\hline $\begin{array}{l}\text { 3. Substifutions for } / \theta / \text { and } / \delta / \\
/ 1 / \text { and } / \mathrm{d} / \text { substitute for } / \theta / \text { and } / \partial / \text { in prevocalic positions, } \\
/ \mathrm{f}, \mathrm{t} / \text { and } / \mathrm{v} / \text { substifute for } / \theta / \text { and } / \delta / \text { in intervocalic } \\
\text { positions and in postvocalic positions }\end{array}$ & STH & 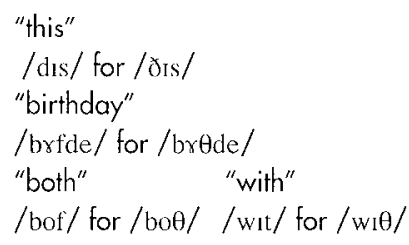 \\
\hline $\begin{array}{l}\text { 4. Devoicing final consonants } \\
\text { Voiceless consonants substitute for voiced following the vowel }\end{array}$ & DFC & /his/ for /hrz/ \\
\hline $\begin{array}{l}\text { 5. Consonant cluster reduction } \\
\text { Deletion of phonemes from consonant clusters }\end{array}$ & CCR & $\begin{array}{l}\text { "world" } \\
\text { /wrl/for /wrld/ }\end{array}$ \\
\hline $\begin{array}{l}\text { 6. Consonant cluster movement } \\
\text { Reversal of phonemes within a cluster, with or without } \\
\text { consonant reduplication }\end{array}$ & $C C M$ & $\begin{array}{l}\text { "escape" } \\
\text { /Ekskep/ for / Eskep/ }\end{array}$ \\
\hline $\begin{array}{l}\text { 7. Syllable deletion } \\
\text { Reduction of an (unstressed) syllable in a multisyllabic word }\end{array}$ & $\mathrm{SDL}$ & $\begin{array}{l}\text { "became" } \\
/ \mathrm{kem} / \text { for / bikem/ }\end{array}$ \\
\hline $\begin{array}{l}\text { 8. Syllable addition } \\
\text { Addition of a syllable to a word, usually as a hypercorrection }\end{array}$ & $S A D$ & $\begin{array}{l}\text { "forests" } \\
\text { /foristsiz/ for / forists/ }\end{array}$ \\
\hline $\begin{array}{l}\text { 9. Monophthongization of diphthongs } \\
\text { Neutralization of diphthong }\end{array}$ & VOW & $\begin{array}{l}\text { "our" } \\
\text { /ar/ substitutes for / aur/ }\end{array}$ \\
\hline
\end{tabular}

Morphosyntactic types

1. Ain't

Ain't used as a negative auxiliary in have+not, do+not, are+not, and is +not constructions

2. Appositive pronoun

Both a pronoun and a noun, or two pronouns, used to signify the same referent

3. Completive done

Done is used to emphasize a recently completed action

4. Double marking

Multiple agreement markers for regular nouns and verbs, and hypercorrection of irregulars

5. Double copula/auxiliary/modal

6. Existential it It is used in place of there to indicate the existence of a referent without adding meaning

7. Fina/sposeta/bouta Abbreviated forms coding imminent action

8. Preterite had Had appears before simple past verbs

9. Indefinite article $A$ is used regardless of the vowel context
AIN "you ain't know that?"

PRO "and the other people they wasn't"

DON "done set the fire"

DMK "he tries to kills him"

"two people felled"

MOD "I' $m$ is the boy"

EIT "I think ir's a girl or a boy is yelling"

FSB "he fitna be ten"

"he bouta fall"

HAD "he flew with a strong stick in his claws while the turtle had held the stick fast in her mouth"

ART "one day she met a eagle traveling to a far-away lands across the sea" 
Table 1 (page 2 of 2). Phonological (9), morphosyntactic (24), and combination (8) types of child AAE with examples.

\begin{tabular}{|c|c|c|}
\hline Definition & Code & Example \\
\hline $\begin{array}{l}\text { 10. Invariant be } \\
\text { Infinitival be coding habitual actions or states }\end{array}$ & IBE & "and they be cold" \\
\hline $\begin{array}{l}\text { 11. Multiple negation } \\
\text { Two or more negatives used in a clause }\end{array}$ & NEG & "it not raining no more" \\
\hline $\begin{array}{l}\text { 12. Regularized reflexive pronoun } \\
\text { Hisself, theyself, theirselves replace reflexive pronouns }\end{array}$ & REF & "bouta fall and trying to hold hisself back up." \\
\hline $\begin{array}{l}\text { 13. Remote past been } \\
\text { Been coding action in the remote past }\end{array}$ & BEN & "I been knew how to swim" \\
\hline $\begin{array}{l}\text { 14. Subject-verb agreement } \\
\text { Subjects and verbs differ in marking of number }\end{array}$ & SVA & "Our cat Mimi like_to sit on the roof" \\
\hline $\begin{array}{l}\text { 15. Undifferentiated pronoun case } \\
\text { Pronoun cases used interchangeably }\end{array}$ & UPC & "her fell" \\
\hline $\begin{array}{l}\text { 16. Zero article } \\
\text { Articles are variably included }\end{array}$ & ZAR & "this cake is (the) best present of all" \\
\hline $\begin{array}{l}\text { 17. Zero copula/auxiliary } \\
\text { Copula and auxiliary forms of the verb to be are variably incluo }\end{array}$ & COP & $\begin{array}{l}\text { "but she always comes down when it (is) time to eat" } \\
\text { "then you'(II) have to wear the brown ones instead" }\end{array}$ \\
\hline $\begin{array}{l}\text { 18. Zero -ing } \\
\text { Present progressive -ing is variably included }\end{array}$ & ING & "It was goling) to be a good birthday" \\
\hline $\begin{array}{l}\text { 19. Zero modal auxiliary } \\
\text { Will, can, do, and have are variably included as modal auxilia }\end{array}$ & AUX & "he might__ been in the car" \\
\hline $\begin{array}{l}\text { 20. Zero past tense } \\
\text {-ed markers are variably included on regular past verbs and } \\
\text { present forms of irregulars are used }\end{array}$ & PST & $\begin{array}{l}\text { "as soon as she open(ed) her mouth, she fall straight into } \\
\text { the ocean below" }\end{array}$ \\
\hline $\begin{array}{l}\text { 21. Zero plural } \\
-s \text { is variably included to mark number }\end{array}$ & ZPL & "Father went out to buy some pretty flower_" \\
\hline $\begin{array}{l}\text { 22. Zero possessive } \\
\text { Possession coded by word order so -s is deleted or the case of } \\
\text { possessive pronouns is changed }\end{array}$ & POS & $\begin{array}{l}\text { "The boy'(s) grandmother showed him how to put worms } \\
\text { on the hook so they would not come off" }\end{array}$ \\
\hline $\begin{array}{l}\text { 23. Zero preposition } \\
\text { Prepositions are variably included }\end{array}$ & ZPR & "she sits and looks (ㅁt) birds" \\
\hline $\begin{array}{l}\text { 24. Zero to } \\
\text { Infinitival to is variably included }\end{array}$ & ZTO & "that man right there getting ready_slip on his one foot" \\
\hline \multicolumn{3}{|c|}{ Combination types } \\
\hline 1. Consonant cluster reduction + zero tense past & $\mathrm{CCR} / \mathrm{PST}$ & "mother kiss(ed) them all goodbye" \\
\hline 2. Consonant cluster reduction plural + zero & $\mathrm{CCR} / \mathrm{ZPL}$ & "the children made their bed(ㅇs and dressed" \\
\hline 3. Consonant cluster reduction + subject-verb agreement & CCR/SVA & "then she jumpls ) on the roof" \\
\hline 4. Postvocalic consonant reduction + zero auxiliary & $\mathrm{PCR} / \mathrm{AUX}$ & "I'(e) lost my blue book" \\
\hline 5. Postrocalic consonant reduction + zero past & $\mathrm{PCR} / \mathrm{PST}$ & $\begin{array}{l}\text { "the boy's grandmother show(ed) him how to put worms } \\
\text { on the hook" }\end{array}$ \\
\hline 6. Postrocalic consonant reduction + zero plural & $\mathrm{PCR} / \mathrm{ZPL}$ & "I can't find my red shoe(s $)^{\prime \prime}$ \\
\hline 7. Postrocalic consonant reduction + possessive & $\mathrm{PCR} / \mathrm{POS}$ & "the boy'()ㅡ grandmother" \\
\hline 8. Postvocalic consonant reduction + subject-verb agreement & $\mathrm{PCR} / \mathrm{SVA}$ & "Mimi go(es) up the tall tree by the house" \\
\hline
\end{tabular}

From: Washington \& Craig, 1994, 2002. Used with permission. 
that past tense consonant cluster reduction is a phonological rather than morphosyntactic rule, assignment of linguistic status of this type has not yet been confirmed and awaits additional research for children. Accordingly, we simply designated these as combinations. The combinations were: consonant cluster reduction + zero past tense, consonant cluster reduction + zero plural, consonant cluster reduction + subject verb agreement, postvocalic consonant reduction + zero auxiliary, postvocalic consonant reduction + zero past, postvocalic consonant reduction + zero plural, postvocalic consonant reduction + possessive, and postvocalic consonant reduction + subject-verb agreement. The following are examples of how these features might occur alone or in combination.

consonant cluster reduction feature:

"One bright summer day a young boy and his ræn/

grandmother walked to a nearby pond to fish." zero past tense feature:

"She became a famous leader of the Underground

Railroad, a secret network of households that provided food and shelter to runaway slaves."

/pravald_/

combination of consonant cluster reduction + zero past tense features:

"As he tried to land the fish, he became so excited that he dropped his pole into the water." /drop_/

\section{Reliability}

Reliabilities were established for the scoring systems. Three independent raters re-scored the reading passages produced by 8 participants. Interrater agreement was calculated by dividing the number of agreements by the number of agreements plus disagreements. Percentage agreements were high across all scoring systems. Interrater agreement on the presence of a reading variation was $86 \%$; agreement on distinguishing $\mathrm{AAE}$ variations from non-AAE variations was $99 \%$; and agreement on distinguishing AAE feature systems as phonological, morphosyntactic, or a combination was $100 \%$. Interrater agreement was $100 \%$ at the level of the individual features.

\section{Results}

Most students $(n=60,94 \%)$ produced AAE features while reading aloud. For the 60 students who produced AAE during oral reading, gender and SES were examined for their potential to influence AAE feature production as measured by the DDM. The results of two independent $t$ tests revealed that DDMs were not systematically influenced by gender, $t(58)=.676, p=.50$, or SES, $t(57)=.256, p=.80$, in this cohort. Accordingly, in subsequent analyses, the data were collapsed across these variables.

The 60 students produced 1,740 instances of variation from print, and 373 instances or approximately $21 \%$ of these variations were identified as AAE features. The mean frequency of occurrence of AAE features across the entire GORT for each student was 6.22 for the students who produced AAE while reading $(S D=5.31)$.

\section{DDMs and Relationships Between Grade and Feature Systems}

Examples of oral reading samples coded for AAE, and given by a second grader and by a fifth grader, are presented in the Appendix. Grade was explored as a systematic source of the large amount of variation in frequencies of feature production. Figure 1 displays the percentage of students at each grade relative to the number of features produced. The second-graders produced 1-11 AAE features, and the third-, fourth-, and fifthgraders produced 1 to 20 or more features. Visual inspection of the figure reveals increasing frequencies of feature production with grade.

Raw frequencies of feature production were confounded, however, by the number of passages that were read by the participants. The third-, fourth-, and fifthgraders read more passages, and these passages were longer so they produced more words than the second-graders. Therefore, the students in the later grades had more opportunities to produce AAE while reading aloud. Accordingly, DDM was used to control for differences in the numbers of words read by each child, and grade was examined for systematic variation. One-way analyses of variance revealed that total DDMs varied significantly by grade, $F(56)=5.59, p=.002$, and overall DDMs decreased from .056 to .016 . A small effect size $\left(\eta^{2}=.231\right)$ was associated with these differences. This effect size likely was due at least in part to the large standard deviations. It is important to note that significant grade differences were detected despite these large standard deviations for DDM within each grade. See Figure 2 for distributions of overall DDMs by grade. Tukey HSD post hoc comparisons revealed that the second-graders produced significantly more $\mathrm{AAE}(p<.05)$, three times more than third-, fourth-, and fifth-graders. After second grade, the DDMs were not significantly different from each other.

These relationships were mirrored for phonological DDMs and combination DDMs, $F(56)=3.38, p=.024$, and $F(56)=3.91, p=.013$, respectively. The effect sizes associated with phonology $\left(\eta^{2}=.153\right)$ and combination $\left(\eta^{2}=\right.$.173) DDMs by grade were small. Again, effect sizes 
Figure 1. Percent of participants using African American English (AAE) features by grade (raw data).

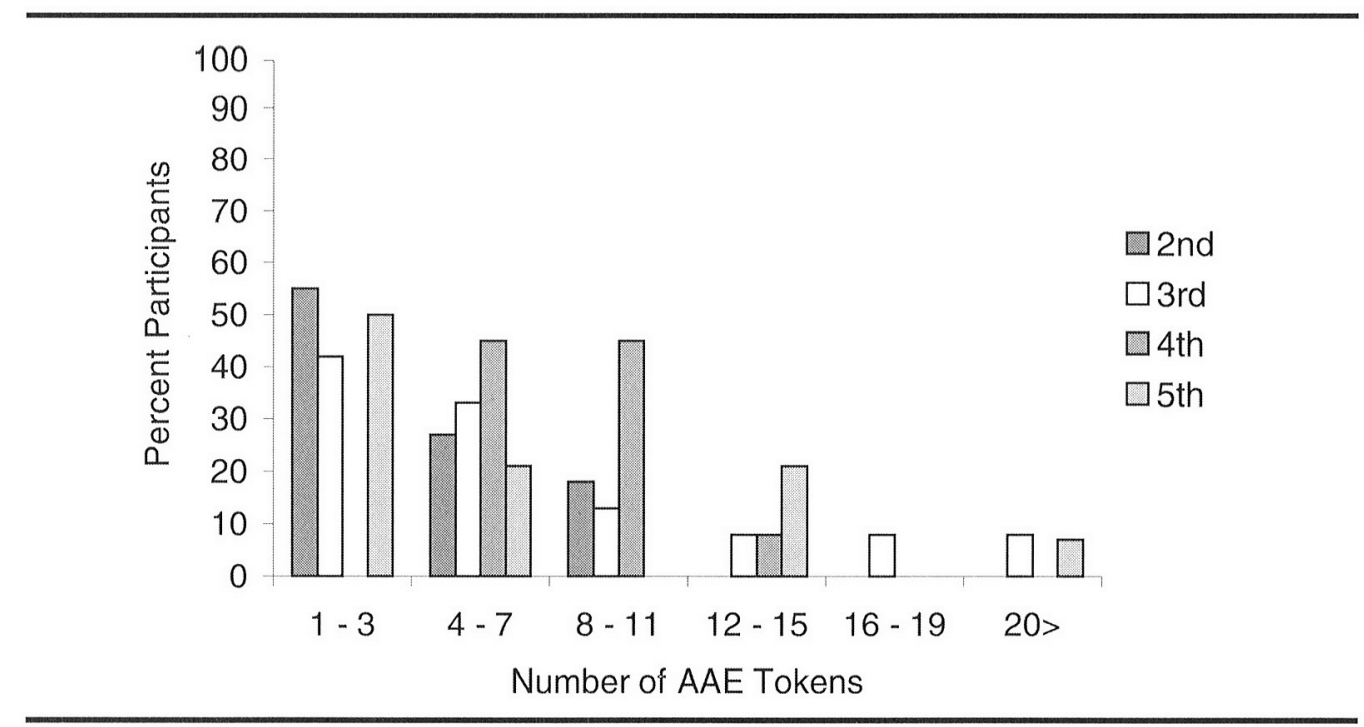

likely were related to the large standard deviations. For phonological and combination feature systems, grade level differences occurred between the second and third grades such that second-grade DDMs were significantly larger (Tukey $p<.05$ ) than the DDMs of the other grades. The magnitude of the differences was two to three times greater for the second grade compared to the third, fourth, and fifth grades (see Table 2). The differences in DDMs for phonology between the second and fourth grade was the single exception, but may relate to the smaller number of participants involved in this comparison. The morphosyntactic DDMs were not significantly different by grade, $F(56)=2.16, p=.103$ (see Table 2).

Next, the three feature systems were compared to each other. Both the phonological feature system (mean DDM $=.011$ ) and combinations (mean DDM $=.010$ ) were produced more frequently than features of the

Figure 2. Overall dialect density measures (DDMs) by grade.

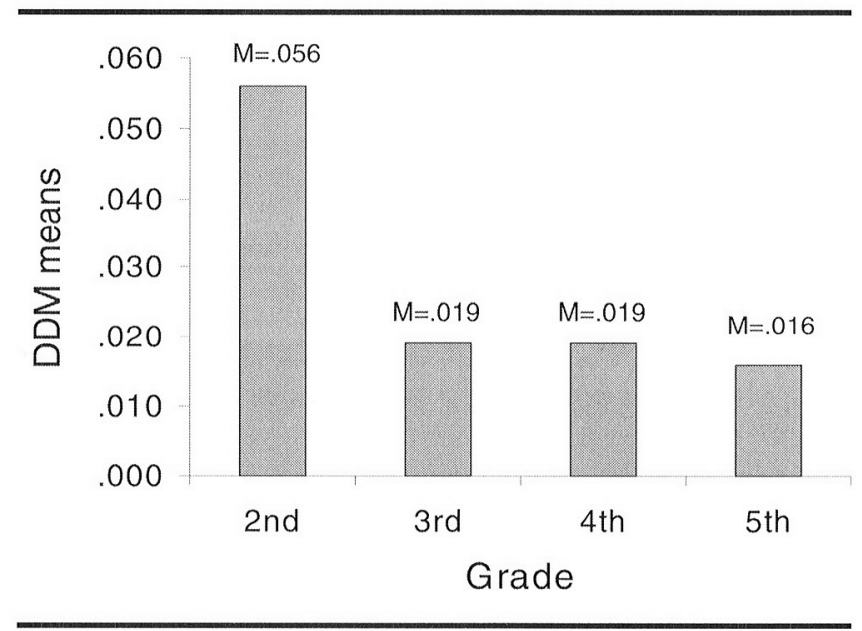

morphosyntactic system (mean DDM $=.003)$, paired $t(59)$ $=4.0, p=.000$, and paired $t(59)=3.3, p=.002$, respectively. ${ }^{1}$ A moderate effect size $(d=.50)$ was associated with significant differences between the phonological and morphosyntactic feature systems. Similarly, significant differences between the combinations and morphosyntactic feature systems yielded a moderate effect size $(d=.41)$. There were no statistically significant differences between frequency of production of features in the phonological system and the combinations, paired $t(59)=.70, p=.486$.

\section{Features Produced While Reading Aloud}

Participants produced all but one of the phonological features at least once during reading (see Figure 3). Monophthongization of diphthongs (57\% of participants), substitutions for $/ \theta /$ and $/ \delta /(45 \%)$, and consonant cluster reduction $(37 \%)$ were the three features most widely dispersed across participants. In contrast, although there were over 500 opportunities for participants to produce devoicing of final consonants (e.g., "It wa(s) going to be a goo(d) birthday.") across the total passages that were read, none occurred (see Figure 3).

Approximately half of the morphosyntactic features were used by the participants who spoke AAE (at least one token or more). The three features that were most widely dispersed across the sample of students were: zero past tense (produced by $17 \%$ of the participants), zero article (produced by $15 \%$ of the participants), and indefinite article (produced by $10 \%$ of the participants).

' $p$ values were corrected $(.05 / 3=.016)$ to adjust for multiple $t$ tests. 
Table 2. Means and standard deviations for DDMs by grade.

\begin{tabular}{|c|c|c|c|c|c|c|c|c|}
\hline \multirow[b]{2}{*}{ DDM } & \multicolumn{2}{|c|}{$\begin{array}{l}\text { Second } \\
(n=11)\end{array}$} & \multicolumn{2}{|c|}{$\begin{array}{l}\text { Third } \\
(n=24)\end{array}$} & \multicolumn{2}{|c|}{$\begin{array}{l}\text { Fourth } \\
(n=11)\end{array}$} & \multicolumn{2}{|c|}{$\begin{array}{c}\text { Fifth } \\
(n=14)\end{array}$} \\
\hline & $M$ & $S D$ & $M$ & $S D$ & $M$ & $S D$ & $M$ & $S D$ \\
\hline Morphosyntactic & .007 & .009 & .002 & .005 & .003 & .003 & .002 & .002 \\
\hline Phonological & $.025^{1,2}$ & .030 & $.010^{1}$ & .011 & .008 & .005 & $.007^{2}$ & .009 \\
\hline Combination & $.024^{3,4,5}$ & .032 & $.007^{3}$ & .010 & $.007^{4}$ & .003 & $.007^{5}$ & .008 \\
\hline
\end{tabular}

Note. Matched superscripts ${ }^{(1-5)}$ indicate significant differences. $p$ values are provided for each.

${ }^{1} p=.05,{ }^{2} p=.03,{ }^{3} p=.012,{ }^{4} p=.05,{ }^{5} p=.04$.

As reflected in the low percentage frequencies, no feature was used by all participants, and all those produced were used by fewer than one-quarter of the participants while reading aloud. None of the participants produced the following 14 morphosyntactic features: ain't, appositive pronoun, completive done, double marking, double copula/auxiliary/modal, existential it, fitna/sposeta / bouta, invariant be, multiple negation, regularized reflexive pronoun, remote past been, undifferentiated pronoun case, zero possessive, or zero "to" during oral reading. Of the 14 morphosyntactic features that were not produced during oral reading, 6 seemed to have no opportunity to occur. This was determined by close inspection of every sentence within the text of all passages read by the students. These features with no apparent opportunity to occur were: ain't, completive done, double copula / auxiliary/modal, fitna/sposeta / bouta, regularized reflexive pronoun, remote past been.

Eight features involved both morphosyntactic and phonological changes and were scored as combinations. Zero past tense and zero plural in combination with consonant cluster reductions ( $45 \%$ and $42 \%$, respectively) were used by more participants than any of the other combinations (see Figure 3).

The above patterns for each major feature system appeared consistent across grades. In order to confirm this apparent pattern, the most frequent feature of each feature system was examined further. For phonological features, monophthongization of diphthongs did not vary systematically by grade, $F(30)=.980, p=.415$. For morphosyntactic features, there were no significant differences by grade for zero past tense, $F(7)=.212, p=.885$. For combination features, consonant cluster reduction + zero past tense did not vary systematically by grade, $F(23)=.726, p=.546$. Therefore, grade differences did not appear to account for the frequency of AAE types produced by students.

\section{Summary}

Of the 41 potential morphosyntactic, phonological, and combination features scored in this analysis, over
$60 \%$ of the types were produced. These analyses revealed that phonological types of child AAE occurred more often than morphosyntactic types.

\section{$\overline{\text { Discussion }}$}

The purpose of this investigation was to examine the phonological features used by elementary-grade African American students. They produced eight of nine phonological features selected for exploration in this study. All but one feature were used by most students (94\% of the participants), and three of the features were used by more than one-third of the participants. This taxonomy, therefore, appears appropriate to the characterization of child-based phonological features of AAE.

Devoicing final consonants was the only phonological feature probed but not observed. It is not clear why students did not use this feature. Findings from a separate investigation of the oral language productions of the same African American students (Thompson, Craig, \& Washington, 2002) revealed productions of the devoicing final consonant feature within a task designed to elicit a spontaneous description of activity pictures, indicating that the students do use the feature, just not in the reading context sampled in this investigation.

Perhaps this discrepancy relates to specific, but at this time unknown, effects of the oral reading context on AAE. AAE production is influenced by language sampling contexts for younger students. Preschoolers and kindergartners produce more instances of morphosyntactic forms of AAE during spontaneous picture descriptions than spontaneous freeplay (Washington et al., 1998). The findings of the present investigation would be consistent with the earlier research if picture description elicits more phonological forms of AAE as well. Further, the three most widely dispersed morphosyntactic features in the present investigation were zero past tense, zero article, and indefinite article. Again, these features were not the highest frequency features observed in prior research with preschoolers and kindergartners during picture description (Washington et al., 
Figure 3. Percent of participants using AAE features. See Table 1 for definition of codes.

\section{Percent Participants Using Phonological Features}

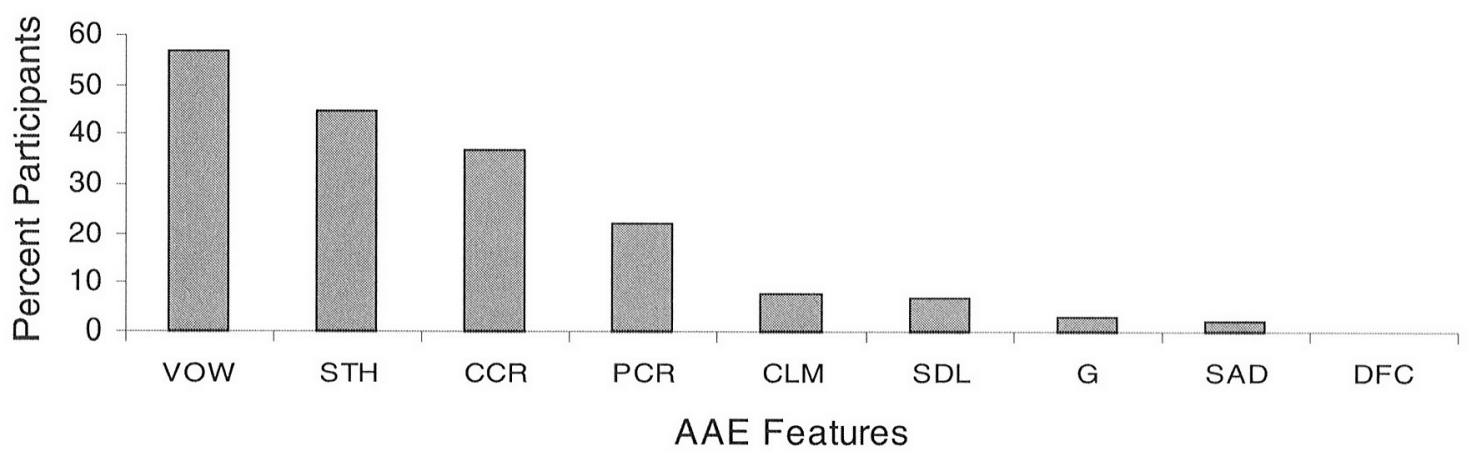

Percent Participants Using Morphosyntactic Features

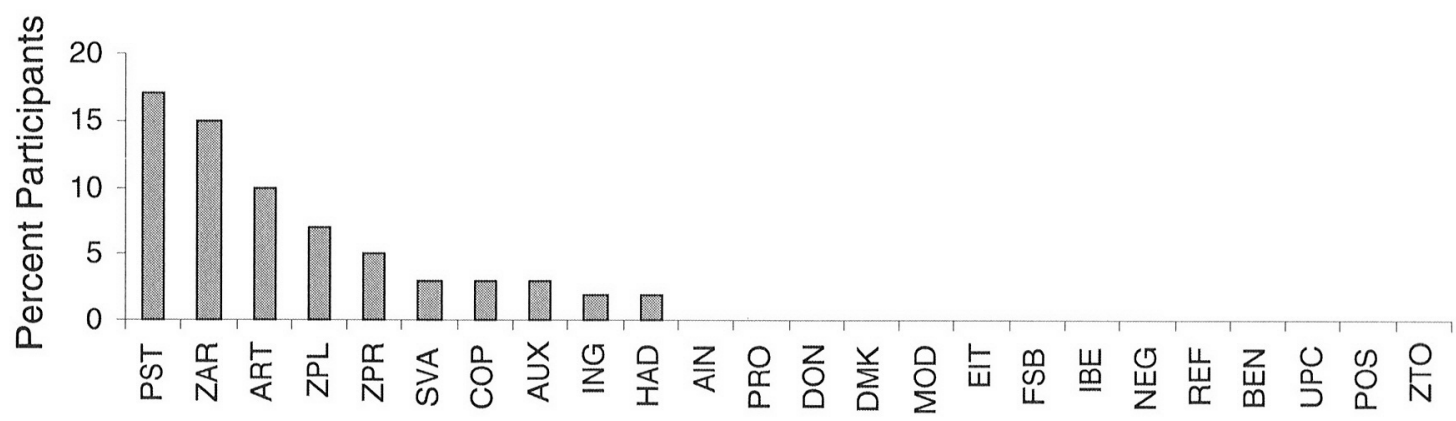

AAE Features

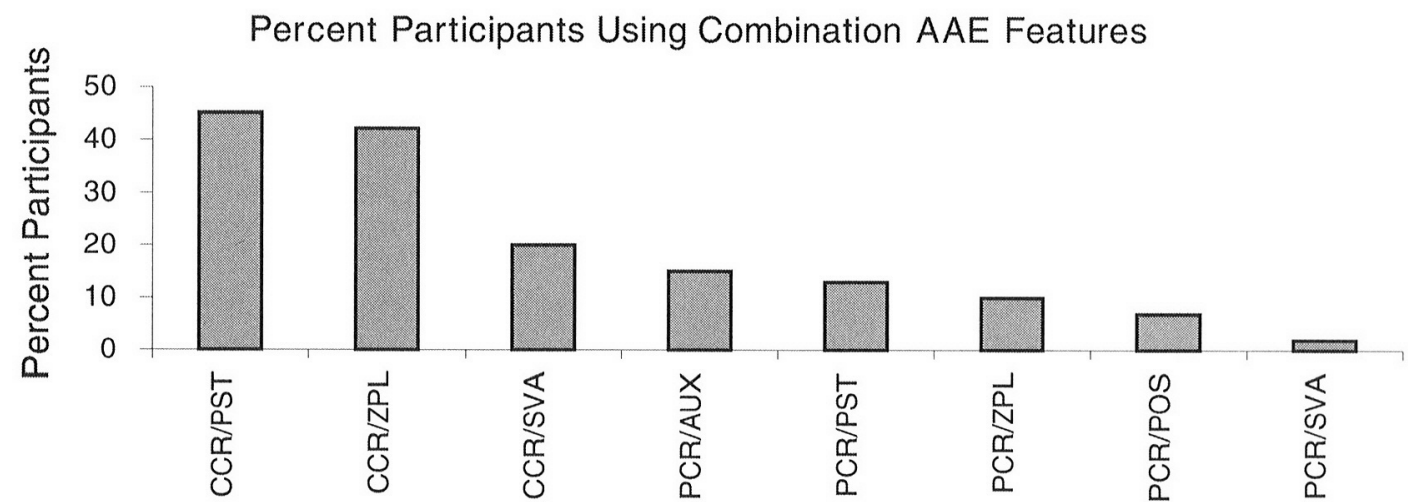

AAE Features

1998) or free play (Washington \& Craig, 1994). The reading passages used as an elicitation context in the present study were written primarily in the past tense, whereas the picture description and free play contexts of the earlier research engaged the children in activities of the present. The similarities and differences in
AAE production by elementary-grade students across language and literacy contexts warrant investigation.

The system of phonological features predominated, and both the phonological system and the system of combinations were produced at more than three times the 
level of morphosyntactic forms. In part, the dominance of the phonological compared to the morphosyntactic system may be due to differences in opportunity. The morphosyntactic features operate at the level of the morpheme, word, or phrase. Although for some morphosyntactic features the morpheme and phoneme are the same (e.g., subject-verb agreement, she sits $\rightarrow$ she sit), the phonological forms operate primarily at the smaller and more frequent unit of analysis, the phoneme. However, phonological feature use decreased by grade in the current investigation, which argues against differential opportunities as an explanation for the differences observed between feature systems. Opportunities for phonological features to occur should be increasing across the grades as students read more complex multisyllabic words. Accordingly, if opportunity were the explanation for differences between the frequencies of occurrence of phonological and morphosyntactic features, then phonological features should increase across grades. An inverse relationship was obtained in the current investigation, indicating that the predominance of phonological features is not an artifact of differential opportunities.

DDM grade differences were detected despite considerable amounts of variability in DDM within grades, suggesting that these are robust differences. Sources of variability in feature production between students has been a focus in past research (Washington \& Craig, 1998; Washington et al., 1998). As additional sources of variability are revealed in the future, grade-level changes may become even more pronounced. As research awaits additional information concerning systematic influences on feature production, however, it is important to note that developmental grade-based changes are still observable. The large variability in feature production across grades in the present study underscores the need to use measures such as DDM to accurately characterize AAE productions. Whereas DDM controls for number of words produced within a language sample, it takes into account differences in feature production based on opportunity at the level of the word. DDM minimizes the variability of feature production associated with differences in the number of words produced in a discourse context. Two factors that did not appear to be sources of variation were SES and gender. Prior research (Craig \& Washington, 2002; Washington \& Craig, 1994, 1998) found SES and gender differences, but the children were much younger and the context was spoken discourse. This may be another example of the unknown ways in which context influences AAE productions of African American children.

Oral reading was selected as the context for examining the production of AAE by elementary-grade students. Consistent with prior examinations of the oral reading of African American students (Baratz \& Shuy,
1969; Gemake, 1981; Goodman \& Buck, 1973; Melmed, 1973; Seymour \& Ralabate, 1985), dialect was produced while reading text written in $\mathrm{SAE}$. The amount of $\mathrm{AAE}$ produced in this literacy context was appreciable; $21 \%$ of the variations from print reflected the operation of an AAE feature. Furthermore, more than $60 \%$ of the types of features identified for potential inclusion were indeed produced. Level of dialect use as measured by DDM for the second-graders averaged .056 or approximately one feature for every 20 words read aloud. There is no reason to assume that this pattern is absent from silent reading and is likely a more general characteristic of the reading activities of African American students. The relationships between AAE and reading warrant further investigation in order to measure the frequency of dialect use and its potential relationships to reading.

In summary, this investigation provides a phonological feature system for child AAE that should prove useful to researchers and practitioners in characterizing AAE production by African American students in the elementary grades. This system of features requires considerable additional study but offers a first step in providing a phonological inventory for examining AAE growth and change with schooling, and the relationship and between overall AAE use and reading acquisition.

\section{Acknowledgments}

This work was supported by the Center for Improvement of Early Reading Achievement (CIERA) at the University of Michigan-U.S. Department of Education, Office of Educational Research and Improvement Grant R305R70004; and by the U.S. Department of Education, Office of Educational Research and Improvement Grant R305T990368. The authors gratefully acknowledge the cooperation of the students, families, and school personnel participating in this study.

\section{References}

Adams, M. J. (1990). Beginning to read: Thinking and learning about print. Cambridge, MA: MIT Press.

Adams, M. J. (2001). Alphabetic anxiety and explicit, systematic phonics instruction: A cognitive science perspective. In S. B. Neuman \& D. K. Dickinson (Eds.), Handbook of early literacy research (pp. 66-80). London: Guilford.

Ball, A. F. (1994). Language, learning, and linguistic competence of African American children: Torrey revisited. Linguistics and Education, 7, 23-46.

Baratz, J. C., \& Shuy, R. W. (1969). Teaching Black children to read. Washington, DC: Center for Applied Linguistics.

Bus, A. G., \& van Ijzendoorn, M. H. (1999). Phonological awareness and early reading: A meta-analysis of experimental training studies. Journal of Educational Psychology, 91, 403-414. 
Craig, H. K., \& Washington, J. A. (1994). The complex syntax skills of poor, urban, African-American preschoolers at school entry. Language, Speech, and Hearing Services in Schools, 25, 181-190.

Craig, H., \& Washington, J. (1995). African-American English and linguistic complexity in preschool discourse: A second look. Language, Speech, and Hearing Services in Schools, 26, 87-93.

Craig, H. K., \& Washington, J. A. (2000). An assessment battery for identifying language impairments in African American children. Journal of Speech, Language, and Hearing Research, 43, 366-379.

Craig, H. K., \& Washington, J. A. (2002). Oral language expectations for African American preschoolers and kindergartners. American Journal of Speech-Language Pathology, 11, 59-70.

Craig, H. K., Washington, J. A., \& Thompson-Porter, C. (1998a). Average C-unit lengths in the discourse of African American children from low-income, urban homes. Journal of Speech, Language, and Hearing Research, 41, 433-444.

Craig, H. K., Washington, J. A., \& Thompson-Porter, C. (1998b). Performances of young African American children on two comprehension tasks. Journal of Speech, Language, and Hearing Research, 41, 445--457.

Dillard, J. L. (1972). Black English: Its history and usage in the United States. New York: Random House.

Donahue, P. L., Finnegan, R. J., Lutkus, A. D., Allen, N. L., \& Campbell, J. R. (2001). The nation's report card: Fourth-grade reading 2000 (NCES 2001-499). Washington, DC: U.S. Department of Education, Office of Educational Research and Improvement, National Center for Education Statistics.

Dunn, L., \& Dunn, L. (1997). Peabody Picture Vocabulary Test-III. Circle Pines, MN: American Guidance Service.

Ehri, L. C., Nunes, S. R., Willows, D. M., Schuster, B. V., Yaghoub-Zadeh, Z., \& Shanahan, T. (2001). Phonemic awareness instruction helps children learn to read: Evidence from the National Reading Panel's metaanalysis. Reading Research Quarterly, 36, 250-287.

Fasold, R. W., \& Wolfram, W. (1970). Some linguistic features of Negro dialect. In R. W. Fasold \& R. W. Shuy (Eds.), Teaching standard English in the inner city (Vol. 6, pp. 41-86). Washington, DC: Center for Applied Linguistics.

Foorman, B. R. (1995). Research on "The Great Debate": Code-oriented versus whole language approaches to reading instruction. School Psychology Review, 24, 376-392.

Foorman, B. R., \& Torgesen, J. (2001). Critical elements of classroom and small-group instruction promote reading success in all children. Learning Disabilities Research \& Practice, 16, 203-212

Gemake, J. S. (1981). Interference of certain dialect elements with reading comprehension for third graders. Reading Improvement, 18, 183-189.

Goodman, K. S., \& Buck, C. (1973). Dialect barriers to reading comprehension revisited. The Reading Teacher, $27(1), 6-12$.

Goswami, U. (2001). Early phonological development and the acquisition of literacy. In S. B. Neuman \& D. K. Dickinson (Eds.), Handbook of early literacy research (pp. 111-125), London: Guilford.
Haynes, W. O., \& Moran, M. J. (1989). A cross-sectional developmental study of final consonant production in southern Black children from preschool through third grade. Language, Speech, and Hearing Services in Schools, $20,400-406$.

Hecht, S. A., Burgess, S. R., Torgesen, J. K., Wagner, R. K., \& Rashotte, C. A. (2000). Explaining social class differences in growth of reading skills from beginning kindergarten through fourth-grade: The role of phonological awareness, rate of access, and print knowledge. Reading \& Writing, 12, 99-127.

Hinton, L. N., \& Pollock, K. E. (2000). Regional variations in the phonological characteristics of African American vernacular English. World Englishes, 19, 59-71.

Hollingshead, A. B. (1975). Four Factor Index of Social Status. New Haven, CT: Yale University, Department of Sociology.

Kaufman, A. (1973). Comparison of the performance of matched groups of Black children and White children on the Wechsler Preschool and Primary Scale of Intelligence. Journal of Consulting and Clinical Psychology, 41, 186-191.

Kaufman, A., \& Kaufman, N. (1983). Kaufman Assessment Battery for Children: Interpretive manual. Circle Pines, $\mathrm{MN}$ : American Guidance Service.

Labov, W. (1972). Language in the inner city. Philadelphia: University of Pennsylvania Press.

Labov, W., Baker, B., Bullock, S., Ross, L., \& Brown, M. (1998). A graphemic-phonemic analysis of the reading errors of inner city children. Unpublished manuscript. Available: http://www.ling.upenn.edu/ wlabov/Papers/GAREC/ GAREC.html.

Lampley, D. A., \& Rust, J. O. (1986). Validation of the Kaufman Assessment Battery for Children with a sample of preschool children. Psychology in the Schools, 23, 131-137.

Melmed, P. J. (1973). Black English phonology: The question of reading interference. In J. L. Laffey \& R. W. Shuy (Eds.), Language differences: Do they interfere? (pp. 70-85). Newark, NJ: International Reading Association.

Oetting, J. B., \& McDonald, J. L. (2001). Nonmainstream dialect use and specific language impairment. Journal of Speech, Language, and Hearing Research, 44, 207-223.

Palmer, D. J., Olivarez, A., Willson, V. L., \& Fordyce, T. (1989). Ethnicity and language dominance: Influence on the prediction of achievement based on intelligence test scores in non-referred and referred samples. Learning Disability Quarterly, 12, 261-274.

Rodekohr, R. K., \& Haynes, W. O. (2001). Differentiating dialect from disorder: A comparison of two processing tasks and a standardized language test. ofournal of Communication Disorders, 34, 255-272.

Seymour, H. N., Bland-Stewart, L., \& Green, L. J. (1998). Difference versus deficit in child African American English. Language, Speech, and Hearing Services in Schools, 29, 96-108.

Seymour, H. N., \& Ralabate, P. K. (1985). The acquisition of a phonologic feature of Black English. Journal of Communication Disorders, 18, 139-148.

Seymour, H. N., \& Seymour, C. M. (1981). Black English and Standard American English contrasts in consonantal 
development of four- and five-year-old children. Journal of Speech and Hearing Disorders, 46, 274-280.

Stewart, W. (1970). Toward a history of American Negro dialects. In F. Williams (Ed.), Language and poverty. Chicago: Markham.

Stockman, I. J. (1996). Phonological development and disorders in African American children. In A. G. Kamhi, K. E. Pollock, \& J. L. Harris (Eds.), Communication development and disorders in African American children (pp. 117153). Baltimore: Paul H. Brookes.

Thompson, C. A., Craig, H. K., \& Washington, J. A. (2002). Variable Production of African American English across oracy and literacy contexts. Manuscript submitted for publication.

Torgesen, J. K., Wagner, R. K., Rashotte, C. A., Burgess, S., \& Hecht, S. A. (1997). The contributions of phonological awareness and rapid automatic naming ability to the growth of word reading skills in second to fifth grade children. Scientific Studies of Reading, 1, 161-185.

Washington, J., \& Craig, H. (1992). Performances of lowincome, African American preschool and kindergarten children on the Peabody Picture Vocabulary Test-Revised. Language, Speech, and Hearing Services in Schools, 23, 329-333.

Washington, J. A., \& Craig, H. K. (1994). Dialectal forms during discourse of poor, urban, African American preschoolers. Journal of Speech and Hearing Research, 37, 816-823.

Washington, J., \& Craig, H. (1998). Socioeconomic status and gender influences on children's dialectal variations. Journal of Speech, Language, and Hearing Research, 41, 618-626.

Washington, J., \& Craig, H. (1999). Performances of atrisk, African American preschoolers on the Peabody Picture Vocabulary Test--III. Language, Speech, and Hearing Services in Schools, 30, 75-82.
Washington, J. A., \& Craig, H. K. (2001). Reading performance and dialectal variation. In J. Harris, A. Kamhi, \& K. Pollock (Eds.), Literacy in African American communities (pp. 147-168). Mahwah, NJ: Erlbaum.

Washington, J. A., \& Craig, H. K. (2002). Morphosyntactic forms of African American English used by young children and their caregivers. Applied Psycholinguistics, $23,209-231$.

Washington, J., Craig, H., \& Kushmaul, A. (1998). Variable use of African American English across two language sampling contexts. Journal of Speech, Language, and Hearing Research, 41, 1115-1124.

Wiederholt, J. L., \& Bryant, B. R. (1992). Gray Oral Reading Tests (3rd ed.). Austin, TX: Pro-Ed.

Willson, V. L., Nolan, R. F., Reynolds, C. R., \& Kamphaus, R. W. (1989). Race and gender effects on item functioning on the Kaufman Assessment Battery for Children. Journal of School Psychology, 27, 289-296.

Wolfram, W. (1971). Black-White speech differences revisited. In W. Wolfram \& N. H. Clarke (Eds.), BlackWhite speech relationships (pp. 139-161). Washington, DC: Center for Applied Linguistics.

Wolfram, W. (1994). The phonology of a sociocultural variety: The case of African American Vernacular English. In J. Bernthal \& N. Bankston (Eds.), Child phonology: Characteristics, assessment and intervention with special populations (pp. 227-244). New York: Thieme.

Received April 25, 2002

Accepted January 17, 2003

DOI: $10.1044 / 1092-4388(2003 / 049)$

Contact author: Connie Thompson, $\mathrm{PhD}$, Center for the Development of Language and Literacy, University of Michigan, 1111 E. Catherine St., Ann Arbor, MI 481092054. E-mail: connietp@umich.edu 
Appendix. Example of an oral reading passage from the GORT-3 by a second- and fifthgrade African American girl.

Variations from print that are features of AAE are underlined, and substitutions and omissions (ø) are indicated on the line below.

\begin{tabular}{ccc} 
Story & Phonological Morphological Combination \\
\hline
\end{tabular}

\section{Second grader}

Our cat Mimi likes to sit on the roof.

/ar/ $\varnothing \quad$ /do/ floor

Mimi goes up the tall tree by the house.

VOW, STH

$\phi$ go

Then she jumps on the roof.

jump down jump on the floor

PCR/SVA

jump down jump
She sits and looks at birds.

sit on an at

But she always comes down when it is time to eat.

CCR/SVA

CCR/SVA

was

Fifth grader

Harriet Tubman lived most of her life working to free

her people. As a young slave, she ran away to the

North. But frequently she returned to the South to help

/norf/
other slaves escape. She became a famous leader of the

STH

ZAR

Underground Railroad, a secret network of households

that provided food and shelter to runaway slaves. provide

Harriet led groups of slaves from one point to another on

the perilous journey north. They traveled only after

nightfall, hiding during the day in basements, fields,

and forests. Harriet was a master of tricks and

disguises, and at one time a reward of $\$ 40,000$ was

diseases

offered for her capture. Her daring rescues helped

hundreds of slaves escape to freedom. As she once said, hundred

"I never lost a passenger."

CCR/PST

$\mathrm{CCR} / \mathrm{ZPL}$

Note. VOW = neutralization of vowels; STH = substitution for $/ \theta /$ and $/ \partial /$ SVA = subject-verb agreement; PCR = postvocalic consonant reduction; $C C R=$ consonant cluster reduction; $Z A R=$ zero article; $P S T$ = zero past tense; $\mathrm{ZPL}=$ zero plural 